\title{
Two-dimensional hydrodynamic flood modelling for populated valley areas of Russian rivers
}

\author{
V. V. Belikov ${ }^{1}$, I. N. Krylenko ${ }^{1,2}$, A. M. Alabyan ${ }^{2}$, A. A. Sazonov ${ }^{2}$, and A. V. Glotko ${ }^{3}$ \\ ${ }^{1}$ Water Problems Institute, Moscow, Russia \\ ${ }^{2}$ Lomonosov Moscow State University, Moscow, Russia \\ ${ }^{3}$ Akvarius Research and Production LLC, Moscow, Russia \\ Correspondence to: I. N. Krylenko (krylenko_i@mail.ru)
}

Received: 17 March 2015 - Accepted: 17 March 2015 - Published: 11 June 2015

\begin{abstract}
Results of flood modelling for three cities located in different parts of Russia: (1) Veliky Ustyug at the Northern Dvina river (Europe); (2) Mezhdurechensk at the Tom river (Siberia); and (3) Blagoveschensk at the Amur river (Far East) are presented. The two-dimensional hydrodynamic model of flow in channels and on floodplain STREAM_2D on the basis of the numerical solution of two-dimensional Saint-Venant equations on a hybrid curvilinear quadrangular and rectangular mesh was used for the simulations. Verification of the model through a comparison of simulated inundated areas with outlines of flooded zones from satellite images for known hydrologic situations demonstrate close correspondence (relative errors of $7-12 \%$ in terms of the area for peaks of the analysed floods). Analyses of embankment influence of large-scale levees on the water flow demonstrate that, in some cases, water levels could rise by more than $1 \mathrm{~m}$ and the patterns of the flooding zones could significantly differ.
\end{abstract}

\section{Introduction}

There are more than 700 cities and towns, thousands of villages and settlements, and more than seven million hectares of agricultural land of the Russian territory are exposed to a risk of flooding. The loss from the biggest floods, such as the extraordinary flood in the Amur basin in 2013, amounts to tens of billion rubles. The total annual damage from flooding in Russia reaches 100 billion rubles (Frolov, 2013). Floods often are followed by losses of human life, as was the case in the city of Krymsk in 2002 and 2012.

One of the ways for decreasing flood damage is reasonable planning of floodplain developments, taking into account possible characteristics of flooding for different scenarios of development and protection simulated by hydrodynamic models. A two-dimensional hydrodynamic model for channel and floodplain flow has been developed by V. V. Belikov and colleagues since the 1990s. It is based on approaches of irregular hybrid computational meshes and original methods of interpolation (Belikov and Semenov, 1988, 2000). Several previous modifications to the computational modules (named RIVER, BOR and FLOOD) are now upgraded and integrated under the name "STREAM_2D". The model has been applied to flooding simulation in numerous key areas on the great Russian rivers: the Volga, the Amur, the Ob, the Lena, etc. (Zaitsev et al., 2004), including the modelling of flooding zones in the case of dambreaks of the main reservoirs.

Detailed information about the topography of the region and the river bed relief is necessary for model setup. Water discharges and water levels at the modelling area boundaries are utilized as the model input. As a result of modelling one can determine the flooded areas and obtain a spatial distribution of flow velocities, water surface levels and depths at any point of the channel and the inundated floodplain.

\section{Study areas}

In this paper we present the results of flood modelling of populated parts of river valleys in three cities located in different parts of Russia: (1) Veliky Ustyug at the Northern Dvina river (Europe); (2) Mezhdurechensk at the Tom river (Siberia); and (3) Blagoveshchensk at the Amur river (Far East) (Fig. 1a). 


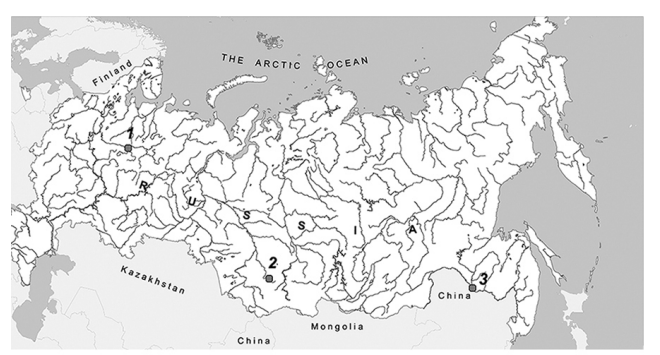

(a)

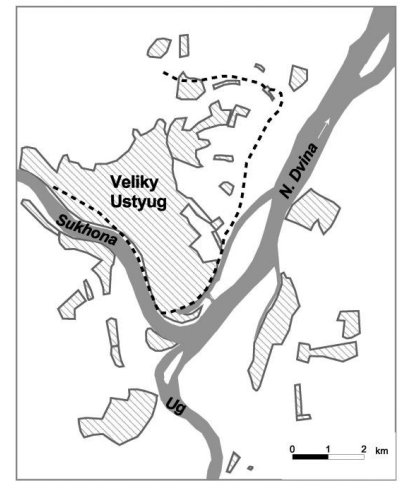

(b)

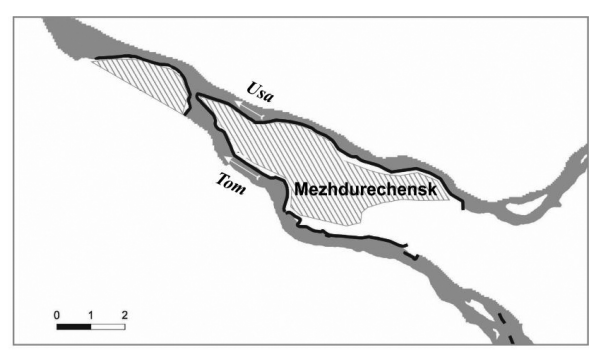

(c)

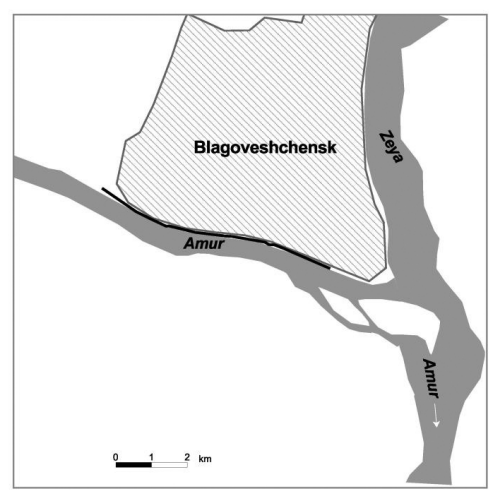

(d)

Figure 1. Case study areas: (a) overall location, (b) Veliky Ustug at the Northern Dvina, (c) Mezdurechensk at the Tom river, (d) Blagoveshensk at the Amur river.

The city of Veliky Ustyug with a population of about 30 thousand is situated in the northern part of European Russia at the confluence of the Sukhona and the Yug rivers (Fig. 1b), and where the Northern Dvina river originates from their junction. It is an ancient Russian city founded in 13th century. During all its history the city was flooded repeatedly. The floods are due to snow melting and ice jams. Ice jams may cause more than $2 \mathrm{~m}$ additional water level rise. The last large flood was observed here in May 1998, when more than half of the city and nearby territories were inundated. A significant flood took place also in April 2013. In this paper we use this case for exploring some specific features concerning the levee efficiency.

The city of Mezhdurechensk is situated in West Siberia on the Tom river at its confluence with the Usa river (Fig. 1c). Its population is about 100000 . The city was founded in the middle of the 20th century as the Siberian centre of the mining industry. The system of levees with a total length of more than $15 \mathrm{~km}$ protects Mezhdurechensk from floods. After the big flood in 1977 when the levees were practically overtopped, they were reconstructed and their height was increased. River valleys near the city are rather narrow - about $2 \mathrm{~km}$. The discharge of $1 \%$ exceedance probability of the Tom and the Usa rivers at the junction are 3640 and $2730 \mathrm{~m}^{3} \mathrm{~s}^{-1}$, respectively. The maximum observed discharge of the Tom river during the flood in May 1977, which was induced by snow melting and additional rainfall, was evaluated

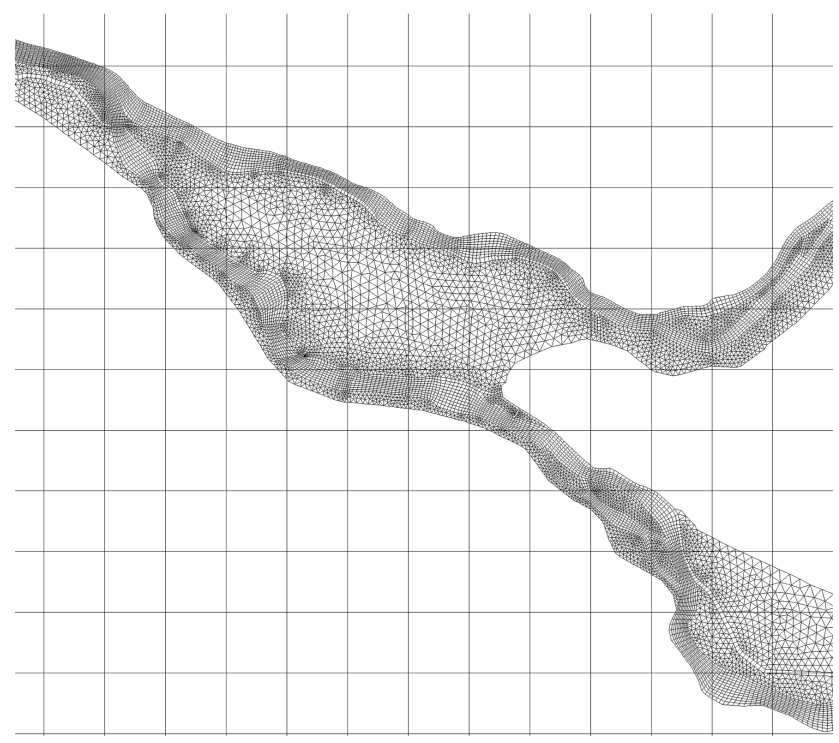

Figure 2. Modelling grid configuration for the Mezhdurechensk city area.

even higher than the discharge of $1 \%$ exceedance probability $-4340 \mathrm{~m}^{3} \mathrm{~s}^{-1}$.

The third case study is the city of Blagoveshchensk (Fig. 1d) with a population of about 200 thousand. It is situated in the Far East of Russia at the Amur river (at the 
confluence of the Amur and the Zeya rivers). The RussianChinese state boundary passes along the Amur river between Blagoveshchensk and Chinese city of Heihe. Floods here are rain induced. The most significant occurred in 1958, when levees were broken and part of the city was flooded; and in 1984, when the streets near the river were inundated. In 2013 the entire Amur basin suffered from flooding, and water levels near Blagoveshchensk raised by more than $9 \mathrm{~m}$. The city was not flooded significantly due to appropriate defence constructions, but other nearby settlements were flooded. The floodplains of the Zeya and the Amur just below the confluence have widths of more than $10 \mathrm{~km}$. Discharges of $1 \%$ exceedance probability of the Amur and the Zeya rivers at their junction are 16700 and $12800 \mathrm{~m}^{3} \mathrm{~s}^{-1}$, respectively. Such discharges were observed in August 1984. During the last flood of 2013, the sum of the maximum discharges of Amur and Zeya at the confluence was slightly lower, with a maximum discharge of $12500 \mathrm{~m}^{3} \mathrm{~s}^{-1}$ for the Amur and a maximum discharge of $13300 \mathrm{~m}^{3} \mathrm{~s}^{-1}$ for the Zeya.

\section{Mathematical and numerical model of flow dynamics}

The basis of the mathematical two-dimensional model consists of the non-stationary equations of Saint-Venant also known as "the shallow water equations". They are widely used in computing the hydraulics of open channels (Cunge et al., 1980). These equations consider the main forces operating on a stream with a free surface (gravity, friction, pressure and inertia; Coriolis's force and wind influence can be considered in addition), and the three-dimensional orography of the land surface.

The system of the Saint-Venant equations in an integrated divergent form (i.e. in the form of conservation laws of mass and momentum) reads as follows (Belikov and Semenov, 1988):

$$
\begin{aligned}
& {\left[\iint_{G} h d G\right]_{t}+\oint_{\sigma} h(d \boldsymbol{\sigma} \times \boldsymbol{w})=0,} \\
& {\left[\iint_{G} h \boldsymbol{w} d G\right]_{t}+\oint_{\sigma} h \boldsymbol{w}(d \boldsymbol{\sigma} \times w)+\frac{1}{2} g \oint_{\sigma} h^{2} d \boldsymbol{\sigma}+g} \\
& \iint_{G} h \nabla z d G=\iint_{G} \boldsymbol{f} d G .
\end{aligned}
$$

where $G$ is the area on the horizontal plane $(x, y), d G$ is the element of an area $G, \sigma$ is the area $G$ border, $d \sigma$ is a vector element of border, $\boldsymbol{w}=\boldsymbol{w}(x, y, t)=(u, v)^{T}$ is a velocity vector, averaged over depth; $(\boldsymbol{a} \times \boldsymbol{b})$ is the scalar product of vectors $\boldsymbol{a}$ and $\boldsymbol{b} ; h=h(x, y, t)$ is the stream depth; $t$ is time; $g$ is acceleration of gravity; $z=z(x, y)$ is topographic elevation; $f$ are external forces, in the actual model friction force $\boldsymbol{f}=\lambda \boldsymbol{w}|\boldsymbol{w}| / 2, \lambda$ is the hydraulic resistance (roughness) coefficient.

This system of shallow water Eqs. (1) and (2) belongs to the type of quasilinear hyperbolic systems and is obtained by averaging the three-dimensional non-stationary equations of Reynolds over the stream depth assuming hydrostatic vertical distribution of pressure.

For solving the system of the Eqs. (1) and (2) the corresponding initial and boundary conditions are needed. At an initial point in time $t=0: \boldsymbol{w}(x, y, 0)=\boldsymbol{w}_{0}(x, y)$ and $h(x, y, 0)=h_{0}(x, y)$. Boundary conditions are established along the borders of the modeled area, for example, water discharge, water level or no flow conditions.

\section{Input data and methodology of modelling}

Detailed information about the topography of the floodplains was used for model setup. Maps of scales 1:25000 and $1: 10000$ were digitized for the Tom and Dvina rivers floodplains. Double satellite images WorldView-1 were utilized as input data of floodplain relief of the Amur river near Blagoveschensk. Data of the riverbed relief, flow velocities, water discharges, and water surface slopes were obtained from detailed field surveys organised by the Lab of soil erosion and river channel processes of the Geography Faculty of Lomonosov Moscow State University.

The discretization of the modelling area in STREAM_2D consists of an irregular hybrid computational mesh. We used curvilinear quadrangular grids with a spatial resolution from about $10 \times 30$ to $40 \times 100 \mathrm{~m}$ for the river channels and linear constructions (such as roads, levees) on the floodplains. The other territories were covered by triangular grid cells with irregular spatial resolution from 50 to $300 \mathrm{~m}$ depending on the necessary level of detail and available topographic information (Fig. 2). All floodplain topography and river channel relief data were interpolated onto the centres of grid cells.

Data of measured flow velocities and water surface slopes obtained during the field campaigns were implemented for model calibration and verification as a first step. Water discharges and water levels at the gauging sites were utilized as the model input for high flood periods. Water levels for gauges located in the cities (Veliky Ustug on the Sukhona, Mezhdurechensk on the Tom, and Blagoveschensk on the Amur) were used as control points for model calibration and validation. More than 5-7 typical hydrological situations with different combinations of river discharges were analysed for each case study.

The satellite images for key areas allow additional validation of the model through comparison of simulated inundated areas with the outlines of flooded zones at the time of peak flow. We used Resource-01 satellite images for the period of high flood at the Northern Dvina river (Veliky Ustyug) in 1998 with a spatial resolution of $30 \mathrm{~m}$ and SPOT5 satellite images with a spatial resolution $10 \mathrm{~m}$ for the flood of 2012 . 
Table 1. Results of model validation.

\begin{tabular}{|c|c|c|c|c|c|c|c|}
\hline \multirow{3}{*}{ Date } & \multirow{3}{*}{$\begin{array}{l}\text { Satellite } \\
\text { image }\end{array}$} & & & \multicolumn{2}{|c|}{ Water levels $(\mathrm{cm})$} & \multicolumn{2}{|c|}{ Flooded area $\left(\mathrm{km}^{2}\right)$} \\
\hline & & \multicolumn{2}{|c|}{$\begin{array}{l}\text { Discharges of the } \\
\text { rivers at their } \\
\text { confluence }\left(\mathrm{m}^{3} \mathrm{~s}^{-1}\right)\end{array}$} & Observed & Simulated & $\begin{array}{l}\text { From } \\
\text { satellite } \\
\text { image }\end{array}$ & Simulated \\
\hline & & Sukhona & $\mathrm{Ug}$ & Veliky & Jstyug & & \\
\hline 11 May 1998 & Resource-01 & 4210 & 2780 & 654 & 653 & 153 & 165 \\
\hline \multirow[t]{2}{*}{5 May 2012} & Spot5 & 3200 & 3900 & 579 & 610 & 143 & 155 \\
\hline & & Amur & Zeya & \multicolumn{2}{|c|}{ Blagoveshensk } & & \\
\hline 14 August 2013 & Radarsat & 13800 & 11407 & 807 & 810 & 54 & 60 \\
\hline
\end{tabular}
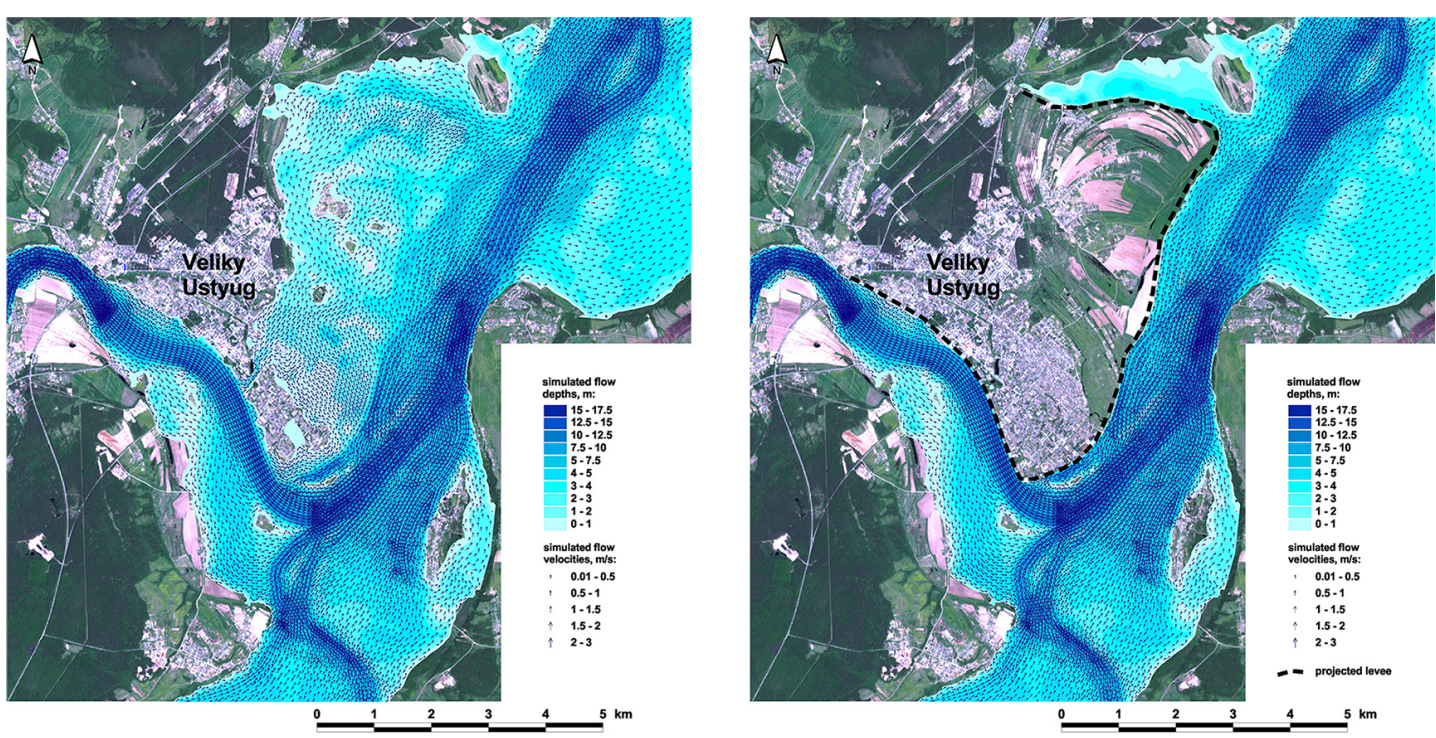

Figure 3. Simulated water depths and flow velocities at Veliky Ustuyg for the runoff induced flood of $1 \%$ exceedance probability: (a) for current conditions, (b) in case of levee construction.

For the flood of 2013 at the Amur river we used Radarsat satellite images with a spatial resolution $6 \mathrm{~m}$ (Table 1). Remote sensing data were provided by ScanEx Research and Development Center (Moscow, Russia).

Periods with ice jams for Veliky Ustyug were taken into account using a rather simple approach based on increasing the roughness and decreasing the water depths for places of ice jams, the specific values of them were obtained during additional model calibration and verification for ice jam periods.

After validating the models, analyses of the impact of large-scale levees on water levels and flow velocities were performed. For this purpose levees were taken into account in the topography data. All simulations for floods of $1 \%$ exceedance probability were carried out twice - with levees and without them.

\section{Results and discussion}

The results of the STREAM_2D model validation for the three case study area demonstrated that the model reproduces the situations rather well. The differences in simulated and observed water levels for the control gauges: "Sukhona - Veliky Ustug", "Tom - Mezhdurechensk", and "Amur Blagoveshensk", never exceeded $30 \mathrm{~cm}$, and the relative errors were $7-12 \%$ in terms of flood area at the time of peak flow (Table 1).

Modelling the $1 \%$ exceedance probability runoff induced flood for Veliky Ustug (which results from a combination of $6500 \mathrm{~m}^{3} \mathrm{~s}^{-1}$ discharge for the Sukhona and $5000 \mathrm{~m}^{3} \mathrm{~s}^{-1}$ for the Yug) showed that in this case one third of the city area will be inundated (Fig. 3a). The water level at the gauge "the Sukhona - Veliky Ustug" for such flood is $800 \mathrm{~cm}$ above the gauge datum, the water depths in the flooded city are about $0.5-1 \mathrm{~m}$ and the flow velocities are relatively small - about 
Table 2. Results of simulation of levee impact.

\begin{tabular}{|c|c|c|c|c|c|}
\hline \multirow{2}{*}{$\begin{array}{l}\text { Place } \\
\text { Veliky Ustyug }\end{array}$} & \multirow[t]{2}{*}{ Date } & \multicolumn{2}{|c|}{$\begin{array}{l}\text { Discharges of the } \\
\text { rivers at their } \\
\text { confluence } \\
\left(\mathrm{m}^{3} \mathrm{~s}^{-1}\right)\end{array}$} & \multirow[t]{2}{*}{$\begin{array}{l}\text { Average water } \\
\text { level increase } \\
\text { along the } \\
\text { levee }(\mathrm{cm})\end{array}$} & \multirow[t]{2}{*}{$\begin{array}{c}\text { Flow } \\
\text { velocity } \\
\text { increase } \\
\left(\mathrm{m} \mathrm{s}^{-1}\right)\end{array}$} \\
\hline & & Sukhona & $\mathrm{Ug}$ & & \\
\hline & $\begin{array}{l}1 \% \text { exceedance probability } \\
\text { runoff induced flood }\end{array}$ & 6500 & 5000 & 30 & 0.2 \\
\hline & $\begin{array}{l}1 \% \text { exceedance probability } \\
\text { ice jam flood (1998) }\end{array}$ & 4000 & 2000 & 120 & 0.2 \\
\hline \multirow[t]{2}{*}{ Mezdurechensk } & & Tom & Usa & & \\
\hline & $\begin{array}{l}\text { Maximum observed flood } \\
\text { (1977) }\end{array}$ & 4340 & 1900 & 100 & 0.5 \\
\hline \multirow[t]{2}{*}{ Blagoveshensk } & & Amur & Zeya & & \\
\hline & $\begin{array}{l}1 \% \text { exceedance probability } \\
\text { runoff induced flood (1984) }\end{array}$ & 16700 & 12800 & 6 & 0.6 \\
\hline
\end{tabular}

$0.15 \mathrm{~m} \mathrm{~s}^{-1}$. The floodplains surrounding the city are also inundated and, as a result, some villages are on the 'islands' between the floodplain flows.

In the case of floods induced by a combination of runoff and ice jams, which takes place at the rivers confluence once per 2-3 years, the situation can be more critical. As an extreme example, we have simulated the maximum runoff observed during ice jams for the entire historical period (discharge of the Sukhona river of $4000 \mathrm{~m}^{3} \mathrm{~s}^{-1}$, discharge of the $\mathrm{Ug}$ river of $2000 \mathrm{~m}^{3} \mathrm{~s}^{-1}$ ) combined a with powerful ice jam. In this case, the water level at the gauging station "the Sukhona-Veliky Ustug" can raise to $1000 \mathrm{~cm}$ above gauge datum, and half of the city can be inundated with maximum depths of more than $1.5 \mathrm{~m}$. A similar extreme flood took place on 5 May 1998 when the water level at gauge "Veliky Ustug" reached $980 \mathrm{~cm}$.

Developing adequate measures for flood-protection of Veliky Ustug city is still a problem. Analyses of different types of levees has shown (Fig. 3b) that such constructions on the one hand should be rather long $(8-12 \mathrm{~km})$ and correspondingly expensive; on the other hand, they will lead to significant flow constriction and concentration on the floodplain. For an extreme runoff and ice-jam induced flood, levee construction would increase water levels throughout the levee length along the Suknona river by more than $1.2 \mathrm{~m}$ (Table 2). As a result, additional populated areas on the remaining floodplains could be inundated. For a $1 \%$ exceedance probability runoff induced flood (without ice jams), this effect is less significant.

Regarding the other case study, Mezdurechesk city was protected by levees from the beginning of its history. The floodplains at the confluence of the Tom and Usa rivers are smaller and less populated than those around the city of Ve- liky Ustug. We analysed the efficiency of the existing levees for a situation of repeating the extreme flood of 1977 . The modelling showed that there is no overtopping of the levees for the current channel conditions. Comparisons of the simulations results with levees and without them demonstrated that, due to levee construction, water levels near the dam increase by $1 \mathrm{~m}$, flow velocities by $0.5 \mathrm{~m} \mathrm{~s}^{-1}$. It is interesting to note that in case of such an event without protection three quarters of the area of the modern city would be flooded with water depths of more than $3.5 \mathrm{~m}$ in some places, and flow velocities of more than $0.5 \mathrm{~m} \mathrm{~s}^{-1}$.

The city of Blagoveshensk is very similar to Mezdurechenk due to its location at the confluence of rivers, and part of the city area is protected by levees. In 2011 a project of constructing new embankments along the Amur river was suggested (Fig. 1d). The possible impact of this construction on river flow was analysed using hydrodynamic modelling before realization of the project. Comparisons of the simulation results for a $1 \%$ exceedance probability flood showed that there should be no significant increase of water levels (only about $6 \mathrm{~cm}$ ) and an increase of flow velocities of $0.5-$ $0.7 \mathrm{~m} \mathrm{~s}^{-1}$ along the levee could be expected.

\section{Conclusions}

The three case studies have demonstrated that hydrodynamic modelling is a powerful tool for scenario analyses for developments of populated parts of floodplains. Analyses of the influence of embankments on river flow showed that, due to flow restriction, levees can significantly (by more than $1 \mathrm{~m}$ ), increase water levels along the constructions and upstream of them. Such effects should be taken into account for the planning of flood protection measures, since they increase 
the flooded areas on the remaining floodplains, and settlements and industries formerly safe could be inundated.

Acknowledgements. The authors sincerely wish to thank the staff of the Lab of soil erosion and river channel processes of Geography Faculty of Lomonosov Moscow State University for the field data and ScanEx Research and Development Center for providing the remote sensing data.

Part of the presented research related to remote sensing was supported by grant of RFBR 13-07-12120 ofi_m. The hydrodynamic modelling and analyses of simulation results were supported by the Russian Science Foundation (grant No. 14-17-00700).

\section{References}

Belikov, V. V. and Semenov, A. Yu.: Godunov's type methods for a numerical solution of the two-dimensional shallow water equations, Proc. 17th Session of Sci. and Methodol, Seminar on Ship Hydrodynamics, Bulgaria, Varna, 2, 56/1-56/6, 1988.

Belikov, V. V. and Semenov, A. Yu.: Non-Sibsonian interpolation on arbitrary system of points in Euclidean space and adaptive isolines generation, Appl. Numer. Math., 32, 371-387, 2000.

Cunge, G. A., Holly, F. M., and Verway, A.: Practical Aspects of Computational River Hydraulics, Pitman Publishing LTD, London, 1980

Frolov, A. V.: Contribution of hydrometeorology in developing of water sector of the country, in: VII All Russian Hydrology congress proceedings, 1-5, 2013 (in Russian).

Zaitsev, A. A., Belikov, V. V., and Militeev, A. N.: Using computer modeling for regulation of sediment transport under hydraulic structures on a large river, Proc. Int. Symp., "Sediment Transfer through the Fluvial System”, IAHS Publ. 386-394, 2004. 